\title{
Improving Public Awareness of Child and Adolescent Health Concerns: Institutional Collaborative Efforts in Brazil
}

\author{
Raquel Rodrigues Máximo de Souza, Priscila Rayanne e Silva Noll, Ana Claudia Martins, \\ Thais Ferreira de Jesus, Daise Fernanda Santos Souza, Ana Luiza Gomes de Souza, Matias Noll
}

Instituto Federal de Educação, Ciência e Tecnologia Goiano-Campus Ceres, Ceres, Brazil

Email: raquelrms2008@gmail.com

How to cite this paper: de Souza, R. R. M., e Silva Noll, P. R., Martins, A. C., de Jesus, T. F., Souza, D. F. S., de Souza, A. L. G., \& Noll, M. (2018). Improving Public Awareness of Child and Adolescent Health Concerns: Institutional Collaborative Efforts in Brazil. Creative Education, 9, 2707-2713. https://doi.org/10.4236/ce.2018.916204

Received: August 16, 2018

Accepted: December 7, 2018

Published: December 10, 2018

Copyright (c) 2018 by authors and Scientific Research Publishing Inc. This work is licensed under the Creative Commons Attribution International License (CC BY 4.0).

http://creativecommons.org/licenses/by/4.0/

\begin{abstract}
The Research Group on Children and Adolescents' Health (GPSaCA) contributes to the construction and socialization of public knowledge by developing scientific research on child and adolescent health. This is an important topic because of the serious lack of attention to the healthcare of these individuals in many parts of the world. The group researches and implements activities to improve healthcare education at its institution. Rigorous studies and activities contribute to the educational process and foster healthy habits.
\end{abstract}

\section{Keywords}

Education, Research, Actions, Health, Children, Adolescents

\section{Introduction}

For many decades, child and adolescent healthcare was the same as adult healthcare, which ignored important and unique aspects of child development. Ariés (2011: p. 9) pointed out that childhood "was not perceived by families or the state as a life stage with specific needs." In this sense, child and adolescent healthcare and relevant policy/programs should take an integrated and articulated perspective regarding social, economic, and political transformations. Figueiredo and Melo (2007) argued that healthcare professionals should articulate and broaden policy guidelines and healthcare practices in response to research and technological developments. This step would reorganize family healthcare practices and focus specific attention on child and adolescent health, which would enhance their health and quality of life. Because children and adolescents have human rights and should be prioritized in educational and healthcare poli- 
cies, Lima (2016) stated that investment in childcare and education is the foundation of a dignified life for future citizens aware of their rights and responsibilities.

To support these goals, Rausc and Schlindwein (2001) proposed that professionals maintain dynamic relationships among themselves and collectively reflect on their research. Multidisciplinary and dynamic training should continually be developed. Discourses and intellectual exchanges among professionals, including open sharing of failures and successes, negotiating interpretations, and challenging conventional opinions are encouraged as good practices. Implementing these activities in educational institutions through research groups improves the teaching/learning process, broadens knowledge, and increases the community's awareness of the importance of paying separate attention to children and adolescents.

This paper reports on the activities of the Research Group on Children and Adolescents' Health (GPSaCA) at the Goiano Federal Institute of Education, Science and Technology, Campus Ceres (IF Goiano - Campus Ceres), in west central Brazil. The research group focuses on child and adolescent health/ healthcare, scientific methodology, biostatistics' courses, healthcare programs, and health-related mathematics. GPSaCA conducts research and extension activities, is registered at the school office, develops projects to expand knowledge on child and adolescent health, and identifies effective ways to promote and share knowledge with the academic community. In weekly meetings, GPSaCA develops educational activities, scientific research, and healthcare programs through research and discussion.

\section{Research Group on Children and Adolescents' Health (GPSaCA)}

Vilaça (2011) indicated that publication and dissemination of scientific studies is beneficial for building knowledge, and electronic scientific journals are important ways to share information. Online publishing provides easy yet broad access to reports, regardless of the institution or country of the readers. Beginning in 2014, the GPSaCA developed a teaching project that has consistently focused on investigating several aspects of child and adolescent health. The activities were conducted at IF Goiano Campus Ceres between September and December of 2017. Its first task was to find the best GPSaCA promotional tool. It had developed a website (www.gpsaca.com.br), which was updated and improved in 2015 when new group members registered (Figure 1).

The website's improvements occurred throughout the teaching project, initially by posting information about the new registered members of the group, updating the meeting schedule to increase participation, and posting information on upcoming events related to the project theme, which enable open access to the group's activities. Recent articles and reports on ongoing projects were posted to increase and promote the availability of the digital content. 


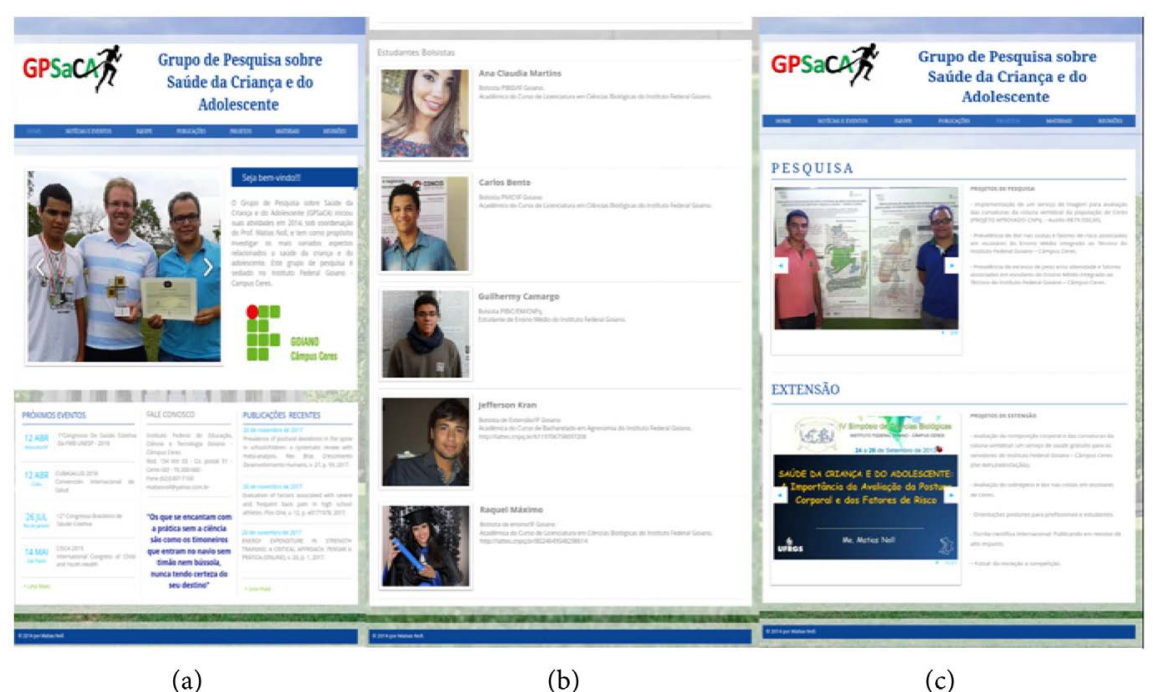

(a)

(b)

(c)

Figure 1. Updated GPSaCA website: (a) home page; (b) current members; and (c) descriptions of ongoing projects. Source: Authors.

Working in groups expands individual and communal knowledge because a variety of perspectives and ideas are shared during group meetings. GPSaCA has a diverse membership of students in biological sciences, information systems, agronomy, and professionals in physical education and nutrition. Weekly group meetings consider studies, literature, discussions, and healthcare promotional activities (Figure 2). Goés (1997: p. 27) pointed out the following regarding the positive potential of group work. "The dialogical game between subjects does not tend to a single direction; rather, it involves circumscription, expansion, dispersion, and stabilization of senses. A certain knowledge (it is either intended, in the intentionality of the other, or previewed, from an observer's perspective) may or may not be built by an individual."

Healthcare promotional activities involving the public were programmed and conducted based on knowledge of current healthcare programs. The first activity focused on the students in the group and IF Goiano Campus Ceres students. Following Louzada et al. (2015), Monteiro et al. (2015), and Fardet et al. (2017), among others, the group created informational banners on healthy food marketing to stimulate children's and adolescents' interest in nutritious food, report on the amounts of sugar in some food products, and highlight sugar synonyms listed on the labels of some processed foods. The banner focused on the diversity of synonyms for "sugar" on processed food labels (Figure 3). Different colors were used so that viewers would carefully read the banner to learn the value of carefully reading food labels (Figure 4). The purpose was to take Penn's (2002: p. 20 advice: "Children undergoing ideal food practices reach their normal development and become healthier adults with a greater reproductive, intellectual capacity." The banner was hung up in the IF Goiano Campus Ceres student restaurant for the public to see. After being exposed to the banners, adolescents' interest in and interaction with the banners were evaluated. 


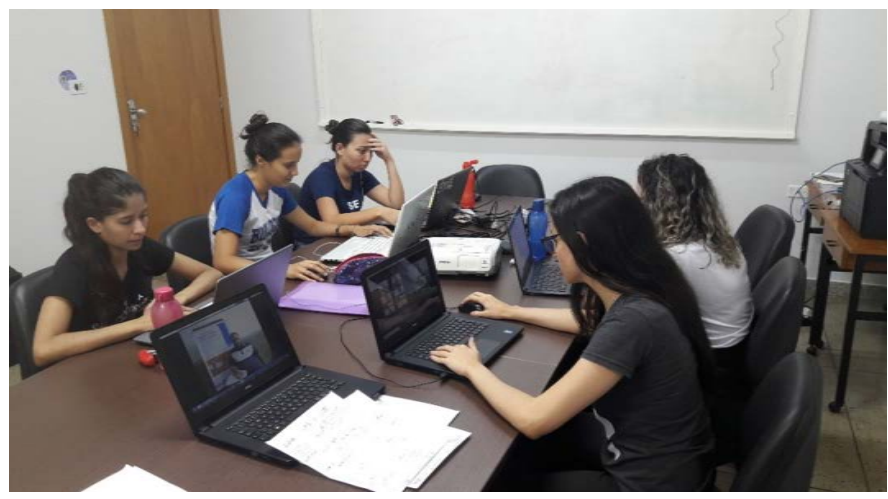

Figure 2. Example of a GPSaCA weekly meeting. Source: Authors.

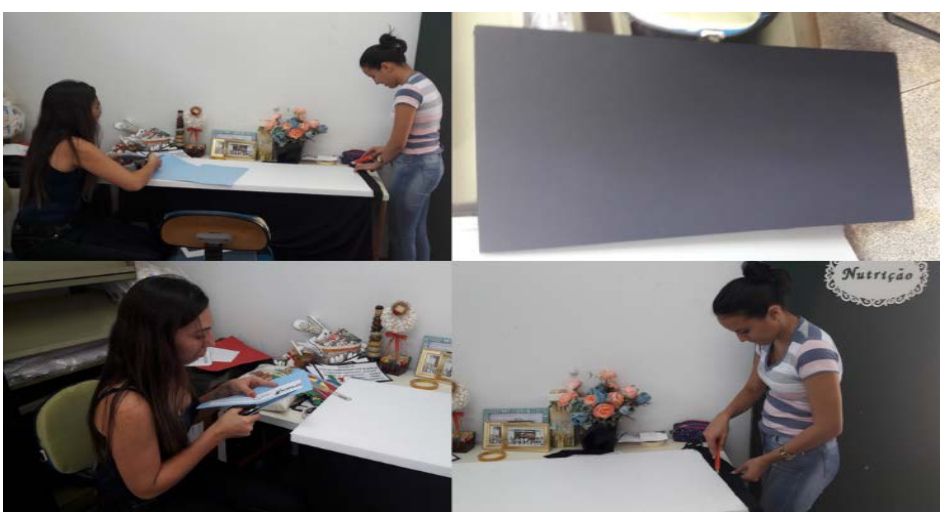

Figure 3. The process of making the banner on synonyms for "sugar". Source: Authors.

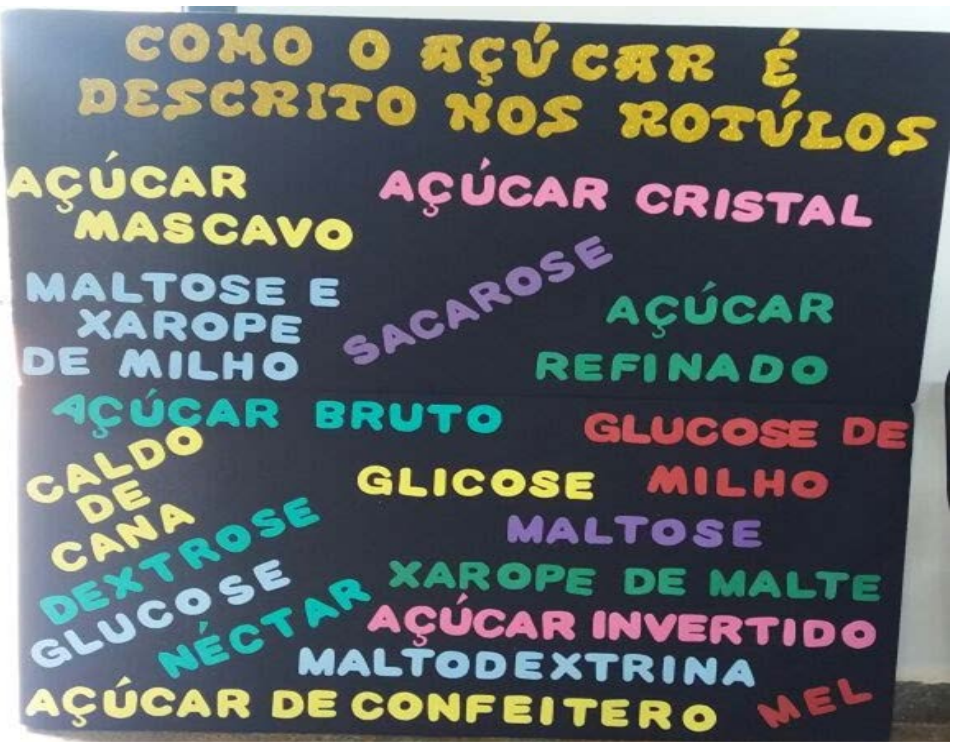

Figure 4. Finished banner on the terms used for "sugar". Source: Authors. Translations: açúcar mascavo (brown sugar), açúcar cristal (granulated sugar), maltose e xarope de milho (maltose andcornsyrup), açúcar bruto (raw sugar), caldo de cana (cane sugar juice), dextrose (dextrose), glucose (glucose), Néctar (nectar), açúcar de confeiteiro (confectioner's sugar), açúcar refinado (refined sugar), glucose de milho (cornsyrup), maltose (maltose), xarope de malte (maplesyrup), açúcar invertido (invert sugar), maltodextrina (maltodextrin), mel (honey). 
A second banner was made to disseminate knowledge and gain attention with the theme of "vegetable league" (Figure 5 and Figure 6), in which vegetables were represented as superheroes to promote healthy eating. The banner was exhibited in the IF Goiano Campus Ceres cafeteria, which is accessible to all students and teachers. The students were very interested, and there were moments when many of them stopped to look and discuss.

The adolescents' interest in and interaction with the vegetable banner were assessed. They expressed interest because they discussed the content with their peers and teachers (Figure 7). They pointed out that, because the health issues were addressed in a context with which they were familiar and interested, they were easy to understand.

According to Proença (2010), industrialization is widely understood as a process that separates people from food, and it might limit perceptions of the origins and/or ingredients of some foods. Nutritional awareness is necessary in the globalizing world. GPSaCA participated in a research project conducted at

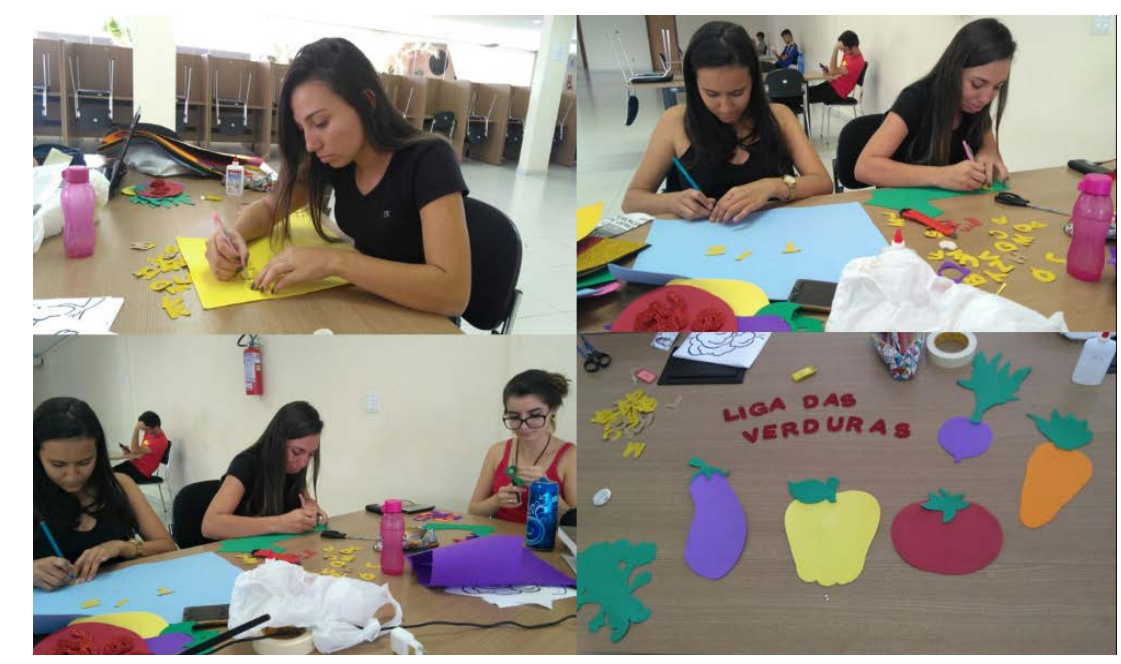

Figure 5. The process of making the vegetable-themed banner. Source: Authors.

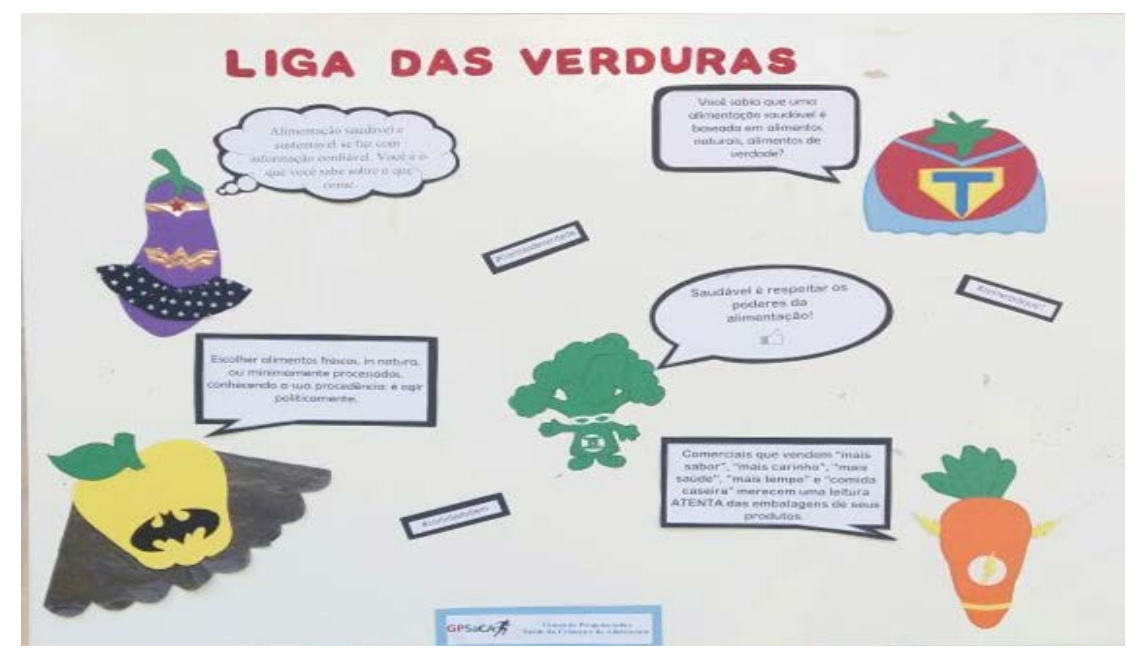

Figure 6. Finished banner of vegetable "superheroes". Source: Authors. 


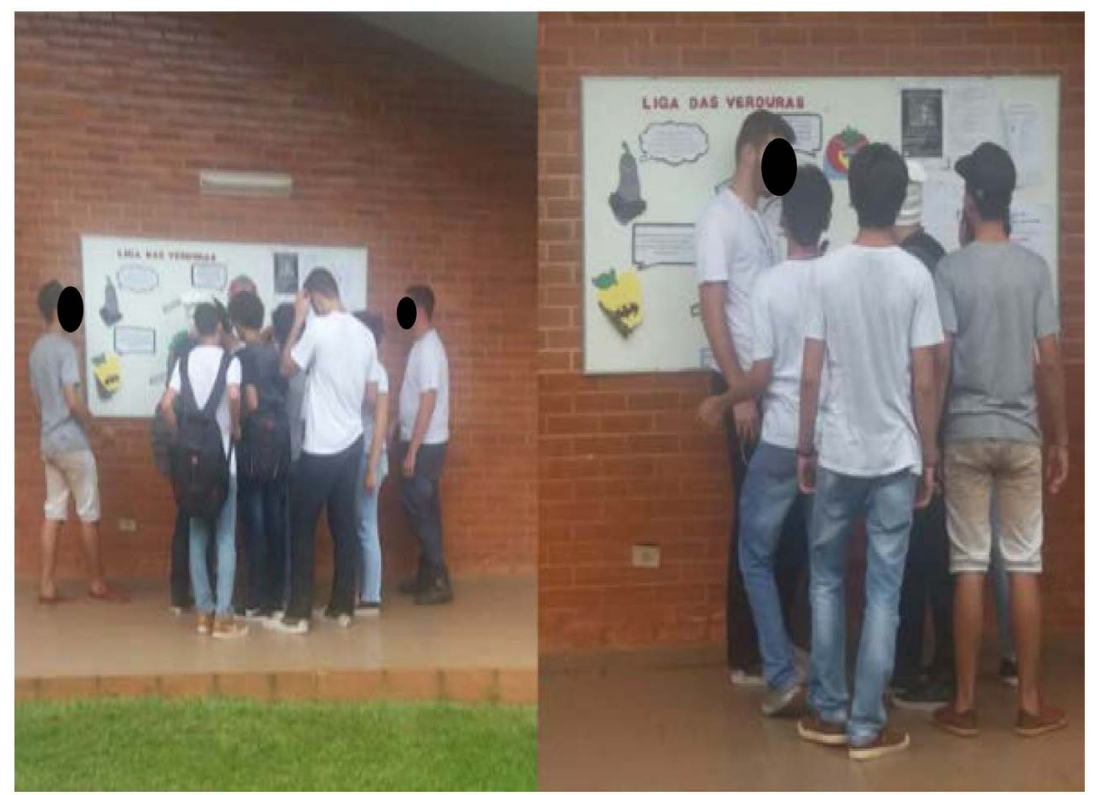

Figure 7. Evidence of interest in the banner. Source: Authors.

the quilombo (Brazilian hinterland settlement founded by former slaves of African origin) of Cedro, in the municipality of Mineiros, state of Goiás, Brazil. Through interviews with the residents, a descriptive case study was conducted on the differences and similarities in body expression, sports, and quilombo games from the emergence of that community to date. The data were collected through observation and semistructured interviews with eight residents older than 18 years of both sexes. These subjects had relevant roles in the community, such as leader, event organizer, young adult, and elder group leader. The researchers observed, interviewed, filmed, and analyzed data.

This study's results increased knowledge on culture, e.g., sports and games, and it was found that the traditional games and sports have disappeared because the children and adolescents no longer played them. The interviewees pointed to the influences of technology as the cause of the decrease in these activities because the children were spending many hours watching television, using mobile phones, and playing video games. The subjects stated that it is important to preserve their culture and that community leaders had already take some steps toward doing so.

\section{Conclusion}

Group activities have the potential to enrich technological and social learning by expanding students' and teachers' knowledge. Collaborative work helps educational institutions and the public to learn about the special healthcare needs of children and adolescents. Collaboration integrates important values, such as generosity and solidarity, which might be weakening in the highly competitive individualism of global society. In response to the lack of attention given to child and adolescent health and to foster public health at educational institutions, the 
GPSaCA developed a variety of health promotions for the public based on scientific reports. Health education must be developed at schools because they are vital to child and adolescent development. Schools should include spaces where discussions on health can occur among educators and students and where healthy behaviors can be promoted through educational processes.

\section{Acknowledgements}

The authors are grateful for the financial support of Campus Ceres-IF Goiano.

\section{Conflicts of Interest}

The authors declare no conflicts of interest regarding the publication of this paper.

\section{References}

Ariés, P. (2011). História social da criança e da família (2th ed.). Rio de Janeiro: Livros técnicos e Científicos.

Fardet, A., Méjean, C., Labouré, H., Andreeva, V. A., \& Feron, G. (2017) The Degree of Processing of Foods Which Are Most Widely Consumed by the French Elderly Population Is Associated with Satiety and Glycemic Potentials and Nutrient Profiles. Food \& Function, 2, 651-658. https://doi.org/10.1039/C6FO01495J

Figueiredo, G. L. A., \& Mello, D. F. (2007). Atenção à saúde da criança no Brasil: Aspectos da vulnerabilidade programética e dos direitos humanos. Revista Latino-americana de Enfermagem, 6, 1171-1176. https://doi.org/10.1590/S0104-11692007000600018

Goés, M. C. R. (1997). As relaçõoes intersubjetivas na construção de conhecimentos. In: M. C. R. Goés, \& A. L. B. A. Simolka (Eds.), Significação nos espaços educacionais: Interação social e subjetivação (pp. 1-28). Campinas: Papirus.

Lima, F. DE F. (2016). A percepção dos enfermeiros da estratégia de saúde da família do território de Manguinhos sobre a sexualidade infantile e a implicação para o cuidado à saúde da criança. Niterói: Universidade Federal Fluminense, Escola de Enfermagem Aurora de Afonso Costa.

Louzada, M. L. da C. et al. (2015) Ultra-Procced Foods and the Nutritional Dietary Profile in Brazil. Revista de Saúde Pública, 49.

http://www.scielo.br/scielo.php?script=sci_arttext\&pid=S0034-89102015000100227

Monteiro, C. A. et al. (2015). Dietary Guidelines to Nourish Humanity and the Planet in the Twenty-First Century. A Blueprint from Brazil. Public Health Nutrition, Cambridge University Press, 13, 2311-2322.

Penn, H. (2002). Primeira infância: A visão do Banco Mundial. Cadernos de Pesquisa, 115, 7-24. https://doi.org/10.1590/S0100-15742002000100001

Proença, R. P. DA. C. (2010). Alimentação e globalização: Algumas reflexões. Ciência e Cultura, 4, 42-47.

http://cienciaecultura.bvs.br/scielo.php?script=sci_arttext\&pid=S0009-67252010000400 $\underline{014}$

Rausc, R. B., \& Schlindwein, L. M. (2001). As ressignificações do pensar/fazer de um grupo de professoras das series iniciais. Contrapontos, 2, 109-123.

Vilaça, M. L. C. (2011). Web 2.0 e Materiais Didáticos de Línguas: Reflexões Necessárias. In: Anais do XV Congresso Nacional de Linguística e Fisiologia. Cadernos do CNLF, 5, 1017-1025. 